\title{
A Phenomenological Study of the Perceptions of Candidate Teachers about the Concepts of School, Teacher and Student in Their Dreams
}

\author{
Sevgi Yıldız \\ Research Assist., Faculty of Educational Sciences, Ankara University, Turkey, \\ yldzsvg@gmail.com
}

\section{Siddıka Gizir}

Assoc. Prof., Faculty of Education, Mersin University, Turkey, sgizir@ gmail.com

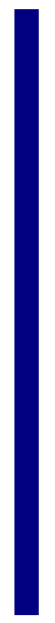

\begin{abstract}
It was aimed in this study to determine through the metaphors how the first and fourth grade candidate teachers in the faculty of education dream of the school, student and teacher and to discuss the findings in the context of teacher training. The sample of the study is composed of 315 candidate teachers (181 in the firstgrade and 134 in the fourth-grade) studying at the Faculty of Education of a university in Turkey. The data of the research were collected with a data collection tool developed by the researchers consisting of 3 questions and content analysis was employed. The similarities-differences between the perceptions of the candidate teachers regarding the related concepts according to the grade variable were determined by frequency analysis. The metaphors that candidate teachers produced for the concept of school in their dreams/wishes gather under 10 themes, for the concept of teacher gather under 9 themes and for the concept of student gather under 9 themes. Each theme that emerged as the result of the analysis was examined according to the grade level of the candidate teachers and it was determined that there are similarities-differences in the perceptions of the candidate teachers for school, teacher and student concepts.
\end{abstract}

Keywords: teacher training, school, teacher, student, candidate teacher

\section{INTRODUCTION}

Education and educational organizations are one of the most important elements of human life. The school is of the leading educational organizations with its origins close to human history. With no common definition, the school has been defined in different ways according to various philosophical and disciplinary fields. According to Aydin (2012), it is a social system that is characterized by the works of individuals and the way they relate to one another for an objective. Şişman (2007) regards the school as a place where individuals prepare for social roles in life, and emphasizes that the school consists a group of people in addition to defining it as an organization, business or family.

Citation: Y1ldı, S., \& Gizir, S. (2018). A Phenomenological Study of the Perceptions of Candidate Teachers about the Concepts of School, Teacher and Student in Their Dreams. International Journal of Instruction, 11(2), 309-324. https://doi.org/10.12973/iji.2018.11221a 
Şişman (2012) also states that school descriptions vary according to different perspectives. From a humanistic point of view, the school is seen as an institution that meets the educational needs of the people associated with the school and should meet the expectations of all stakeholders while, in a rational perspective, it is accepted as structures created to achieve specific goals like other organizations and businesses. In this respect, the primary task of the school is to preserve and maintain social stability, harmony and integrity. When considered in terms of system theory, the school is a structure that transforms some inputs (knowledge, human, technology, money, etc.) into a service or product and presents it to its environment while it is seen, in terms of critical theory, as a place where critical thinking is gained, and critical knowledge is produced, taught and practiced. In addition, according to critical theory, school is a means of shaping and regenerating society. From an objective point of view, the centrally developed models and approaches are applied at schools which are seen as universal institutions; on the other hand, unlike the objective viewpoint, the subjective approach, recognizing that there may be differences between the schools, defines it as a peculiar living space that is given a meaning by the shareholders living in the school (Şişman, 2012). However, according to the organizational learning approach, the school works as a service organization in which the teaching and learning objectives are to be realized and the ultimate goal of the school is to ensure student learning. According to the social system approach, the school is a network of complex social relations built by interconnected parts and a certain group of people, and the main purpose of the school is to prepare students for adult roles (Hoy and Miskel, 2010).

Although there is no consensus on the definition and function of the school, it is seen that all perspectives have a common view that the main actors of the school are students and teachers. The legal position of the teaching profession is regulated by Article 43 of the Basic Law of National Education No. 1739 and, according to this, teaching is defined as a specialist profession undertaking the state's education, teaching and related administrative duties. It is stated that preparation for the teaching profession is provided by general culture, special field education and pedagogical formation (Ministry of National Education, 2009). Therefore, teaching is considered as a profession that requires specialized knowledge and skills. Teachers need to have specific competences for the learning-teaching process (planning, teaching process, classroom management, communication, etc.) as well as the field knowledge, teaching profession knowledge and general culture. In addition to these qualifications, a teacher also undertakes many different roles at the same time. Teachers' main roles can be listed as representation, leadership, information resource, mediation, arbitration, judgeship, tutorial, parenting, guidance-confidentiality and counselling. Teacher roles and approaches to teachers have also changed in line with the changing school perspectives and definitions.

On the other hand, the student, one of the main actors of education, is defined as the person who is trying to achieve the learning experiences required by a pre-designed training program in a planned educational environment (Başaran, 2006) and they are seen as the reason for the existence of the school. Erdem (2013) argues that the school should provide services to increase the quality of education in order to make students achieve its educational goals. However, teachers must be extremely careful in their 
relationships with students. It is stated in the literature that the students are influenced by the behaviours of the teachers, they take them role models and this effect is reflected in their attitudes and behaviours of later life (Cerit, 2008, Erdem, 2013; Şişman, 2012).

As a result of defining the relationship between the main actors of education such as teachers and students and the school in various forms according to different approaches, the perceptions of these concepts may change. Saban, Koçbeker and Saban (2006) emphasize that metaphor, a powerful mental instrument, is an effective tool to see how phenomena or events are perceived while Arslan and Bayrakçı (2006) underline that metaphors help us see a phenomenon or an event from other people's eyes or understand and construct a concept domain within the framework of another concept. Similarly, Yıldırım and Şimşek (2013) express that complex ideas, meanings, explanations and associations become understandable in a wide variety of fields through metaphors and they present a comprehensive picture about the subject, case, event or situation being examined.

\section{Metaphors in Educational Researches}

Educational metaphors are widely used in educational researches and practices. Balc1 (1999) states that educational researchers see metaphor as a means to explain the current phases of educational practices. Balc1 (2008) expresses that people use metaphor as a tool in understanding and studying the current situation of education practices. Metaphores are used to reveal the problems in education practices of basic fields such as teacher education, classroom management, education management and counselling, to find solutions to these problems, and to gather information about ideas and opinions in different areas (Balc1, 1999). For instance, in educational administration, metaphors are employed in curriculum development and planning while they are applied in teaching to encourage learning and develop creative thinking. In teacher training, metaphors are used to guide teaching practices and to identify teachers' positions in modern education approaches (Vadeboncoeur and Torres, 2003) and support for teacher-student relationships (Casebeer, 2015). Martínez, Sauleda, and Huber (2001) point out that metaphors have a strong impact on the process of analysis and planning in education.

Arslan and Bayrakçı (2006) emphasize that the metaphor is a powerful mental mapping and modeling mechanism to understand and construct the worlds of individuals. Though quantitative researches are frequently carried out on many dimensions of candidate teachers, the need for the studies in the qualitative research type is also getting important (Başkonuş, Akdal and Taşdemir, 2011). Similarly, Işıkoğlu (2005) states that qualitative research studies in educational sciences and teacher training areas are developing gradually. On the other hand, since metaphors help us see a phenomenon or an event from other people's eyes or understand and construct a concept domain within the framework of another concept and are a powerful mental mapping and modeling mechanism to understand and construct the worlds of individuals (Arslan and Bayrakçı, 2006), the opinions of teachers of the future about how these concepts should be organized can be regarded important especially for the future teacher training policies.

\section{Purpose of the Study}

Teacher training programs in higher education institutions are accepted as the first stage 
of preparation for the teaching profession. However, it is also true that candidate teachers have many experiences during their school years before training starts. Experiences of candidate teachers during their school years and their university education provide a source for their future attitudes and behaviors (Baki and Gökçek, 2007). Regarding this information, it was aimed in this research to determine through the metaphors how the first and fourth grade candidate teachers in the faculty of education dream of the school, student and teacher and to discuss the findings in the context of teacher training. Answers to the following questions were sought within the scope of this general purpose:

1. What are the perceptions of candidate teachers for the concepts of school, student and teacher in their dreams?

2. According to the grade variable, what are the similarities and differences in the perceptions of candidate teachers for the concepts of school, student and teacher in their dreams?

\section{METHOD}

\section{Research Design}

A qualitative research approach was employed in this study. As phenomenology is concerned with how people perceive a phenomenon, how they remember, how they evaluate it, and how it relates to other people, phenomenology of the qualitative research patterns was chosen in this study. Phenomenology is a science that investigates how people understand, perceive, and transfer their experiences to their minds (Patton, 2014). Therefore, in this study, metaphors forming a strong mental structure to understand individuals' thoughts (Palmquist, 2001) were used as a means of obtaining data.

\section{Population and Sample}

Education faculty of a university in Turkey is determined as a case in this study. In 2015-2016 spring semester, a total of 422 first-year students and a total of 510 fourthyear students attended six different programs in the faculty: Computer Education and Instructional Technologies (CEIT), Preschool Education (PE), Guidance and Psychological Counseling (GPC), Social Sciences Education (SSE), Classroom Instruction Education (CIE) and Special Education (SE). Since a total of 932 students were considered to be accessible, no sampling technique was used in this study, and the entire universe was tried to be reached.

Fourth grade students were included in the sample of the study as they were thought to have achieved a certain level of awareness of the concepts covered in this study through their academic and social experiences during their education at the Faculty of Education and to have internalized the faculty culture. On the other hand, first grade students were included in the study due to the fact that their academic and social experiences were low as they were new at the faculty and that they were foreign to the faculty culture as they did not have sufficient interaction with academic and administrative staff as well as inclass and out-of-class communities, which shows that their perceptions of the concepts examined in the study were not yet influenced by their learning process. It is considered 
that how their perceptions of the concepts covered in the study have changed through their education at the faculty of education can be observed. Because the students' participation in the survey was voluntary and some students did not fill out the data collection tool properly, the data from 315 candidate teachers (181 in the first grade and 134 in the fourth grade) were included in the analysis. Gender and grade information according to the departments of the candidate teachers in the sample are presented in Table 1

Table 1

Distribution of Candidate teachers by Department, Gender and Classes

\begin{tabular}{llccccccc}
\hline Variables & & CEIT & PE & GPC & SSE & CIE & SE & Total \\
\hline \multirow{2}{*}{ Gender } & Female & 17 & 61 & 30 & 35 & 62 & 27 & 242 \\
& Male & 8 & 6 & 11 & 17 & 16 & 15 & 73 \\
Grade & First & 20 & 32 & 25 & 32 & 48 & 24 & 181 \\
Total & Fourth & 5 & 35 & 16 & 20 & 40 & 18 & 134 \\
\hline
\end{tabular}

Computer Education and Instructional Technologies (CEIT), Preschool Education (PE), Guidance and Psychological Counseling (GPC), Social Sciences Education (SSE), Classroom Instruction Education (CIE) and Special Education (SE).

As seen in Table 1, the sample of the study is in line with the demographic structure of the faculty. According to this, approximately $77 \%$ of the participants in the survey are female candidate teachers. First graders constitute approximately $58 \%$ of the sample. Classroom, pre-school and social studies teachers are the most frequently represented departments in the sample respectively.

\section{Data Collection Tool and Data Collection}

In this study, the data collection tool was developed by the researchers in regard to the relevant literature and research questions. The draft interview form was evaluated in terms of content, consistency, grammar and intelligibility by three lecturers, two of whom are in the educational sciences, and one of whom is a specialist in Turkish Language and Literature. A pilot study was conducted to determine the intelligibility of the expressions, the writing style and the duration of the application of the data collection tool. In this context, the researcher carried out a pilot study with 20 students from the second and third grades of the faculty. It was observed as a result of this study that participants produced metaphors with general and book descriptions for ideal school, teacher and student concepts. Therefore, revisions were made to prevent this situation in the data collection tool and the final form was created. The data collection tool has two parts: in the first part, there are questions about gender, department and grade, and in the second part, the questions were asked to determine the metaphors of the participants on the concepts of "the school, student and teacher in their dreams/wishes". The candidate teachers were asked to produce metaphors for each concept in this context. For example, they were asked to complete the sentence about the school concept, "The school in my dream is like ...... because .....". They were required to deepen the meaning by explaining their metaphors because individuals may assign different meanings to similar metaphors. The data of the study were obtained from the first and fourth grade students studying at the Faculty of Education during the 2015- 
2016 spring academic year. After giving the necessary information about the study, data collection tool was applied to the candidate teachers participating in the research on a volunteer basis.

\section{Analysis of Data}

After the data collection process, the data were analyzed by content analysis. The purpose of content analysis is to get concepts and associations that can explain the data. The basic process in content analysis is to bring the data together in a frame of specific concepts and themes, and to edit and interpret them. In addition, according to Yildirim and Şimşek (2013), it is necessary to make detailed descriptions, in other words to give direct quotations, in order to provide validity and reliability. For this purpose, the findings of the research were supported by direct quotations.

\section{FINDINGS}

The findings obtained through the analysis are presented under the themes determined for the concepts covered in the study and the relevant literature is taken into consideration.

\section{Perceptions of Candidate Teachers for the Concept of "School in Their Dreams"}

As a result of the analysis, it was found that the candidate teachers produced 313 metaphors for the school concept in their dreams, and these metaphors are seen to gather under 10 themes. The themes that emerged as the result of the analysis of the metaphors produced by the candidate teachers and the sample participant opinions of these themes are presented in Table 2.

Table 2

Sample Metaphors and Themes That All Participants Produced for School Concept in Their Dreams

Theme 1. School as information centre

C102-"My dream school is like the Academy of Plato. Because there is literally education, information and questioning."

Theme 2. Multifunctional school

C150-"My dream school is like an advanced place in terms of sociability. Because social activities and acquiring social skills as well as education will contribute a lot to the students."

Theme 3. Multicultural school

C181-"My dream school is like colors. Because it should accommodate many students with different characteristics. These colors must blend together to create new colors."

Theme 4. Natural and free school

C34-"My dream school is like nature. Because, instead of inside the walls, education should be done as natural and in free environments as possible."

Theme 5. Entertaining and interesting school

C8-"My dream school is like the school in the Harry Potter movie. Because the school should be interesting, entertaining, full of activities and also educational while having fun."

Theme 6. Small and equipped school

C289-"My dream school is like Montessori school type. Because all the necessary tools are given to the students. Students learn by doing and living in small schools."

Theme 7. Modern and technological school

C25-"My dream school is like a technology environment. Because I believe that students will be 
given a better education using technological tools."

Theme 8. Non-existing School

C12-"My dream school is like a pink graveyard. Because even though it looks nice, it's a complete asylum, better when there is no school."

Theme 9. Authoritarian school

C302-"My dream school is like a house. Because there are some rules. Students have to be disciplined."

Theme 10. Warm and friendly school

C305-"My dream school is like a home. Because it is peaceful, comfortable, safe, and there must be confidence, love and respect relationship between student and teacher."

On the other hand, regarding the grade level, in order to determine the similarities and differences in the perceptions of candidate teachers for the concept of school in their dreams, the related themes are organized according to the frequency percentage. In Table 3, frequency and percentages are shown as to the similarities and differences in the perceptions of candidate teachers for the concept of school in their dreams according to the grade level.

Table 3

Percentage of Similarities and Differences in the Perceptions of Participants for School Concept in Their Dreams by Their Grade Level

\begin{tabular}{lllll}
\hline \multirow{2}{*}{ Themes } & $\begin{array}{l}\text { First Graders } \\
\text { Number of } \\
\text { Metaphors }\end{array}$ & $\begin{array}{l}\text { Percentage } \\
(\%)\end{array}$ & $\begin{array}{l}\text { Fourth Graders } \\
\text { Number of } \\
\text { Metaphors }\end{array}$ & $\begin{array}{l}\text { Percentage } \\
(\%)\end{array}$ \\
\hline School as information centre & 17 & 9.3 & 26 & 19.6 \\
Entertaining and interesting school & 34 & 18.7 & 15 & 11.3 \\
Natural and free school & 25 & 13.8 & 24 & 18.1 \\
Modern and technological school & 30 & 16.5 & 17 & 12.8 \\
Warm and friendly school & 42 & 23.2 & 27 & 20.4 \\
Non-existing school & 5 & 2.7 & 1 & 0.0 \\
Multicultural school & 10 & 5.5 & 10 & 7.5 \\
Multifunctional school & 13 & 7.1 & 7 & 5.3 \\
Small and equipped school & 2 & 1.1 & 3 & 2.2 \\
Authoritarian school & 3 & 1.6 & 2 & 1.5 \\
\hline
\end{tabular}

According to Table 3, in the themes of school as information centre and entertaining and interesting school, relatively distinct differences are seen between the first and fourth graders. When evaluated in general terms, the students in the first grade wished for the school to be entertaining and interesting more than the students in the fourth grade. On the other hand, the fourth-grade students pointed out more to the school that produced and distributed information. Their views about other themes seem to be relatively similar.

\section{Perceptions of Candidate Teachers for the Concept of "Teacher in Their Dreams/Wishes"}

As a result of the analysis, it was found that the candidate teachers produced 312 metaphors for the teacher concept in their dreams/wishes, and these metaphors are seen to gather under 9 themes. Sample metaphors from the themes and participants for the concept of teacher are shown in Table 4. 
Table 4

Sample Metaphors and Themes That All Participants Produced for "Teacher" Concept in Their Dreams/Wishes

Theme 1. Information-source teacher

C56-"My dream teacher is like a lion. Because he must have a comprehensive knowledge, be wise and experienced."

Theme 2. Highly qualified teacher

C51- "My dream teacher is like Atatürk. Because he was disciplined, hardworking, virtuous and scientific. He was a foresighted person working for his people."

Theme 3. Lesson-focused teacher

C143-“My dream teacher is like a robot. Because it's enough to teach the lesson. It's not nice to force participation and give a lot of homework."

Theme 4. Self-improving teacher

C7-“ My dream teacher is like a truck of which brake has failed. Because he must constantly search for things, no obstacles should stop him. He must work hard to be a dream teacher of his students."

Theme 5. Authoritarian teacher

C159-"My dream teacher is like a father. Because he keeps the distance with the students and does not allow the students to disrespect himself."

Theme 6. Student-centered teacher

C121-"My dream teacher is like a god. Because he needs to predict and organize the environment in which students can satisfy their needs and realize themselves."

Theme 7. Warm and friendly teacher

C245-"My dream teacher is like a mother. Because he must be affectionate, full of love and concerned like a mother."

Theme 8. Coherent teacher

C63- "My dream teacher is like a parent. Because he should love us, be affectionate but get angry with us when necessary."

Theme 9. Leading teacher

C158-"My dream teacher is like a lighthouse. Because the teacher should show the way to the students like a lighthouse in the endless sea."

On the other hand, regarding the grade level, in order to determine the similarities and differences in the perceptions of candidate teachers for the concept of teacher in their dreams/wishes, the related themes are organized according to the frequency percentage. In Table 5, frequency and percentages are shown as to the similarities and differences in the perceptions of candidate teachers for the concept of teacher in their dreams/wishes according to the grade level.

Table 5

Percentage of Similarities and Differences in the Perceptions of Participants for Teacher Concept in Their Dreams/Wishes by Their Grade Level

\begin{tabular}{lllll}
\hline Themes & $\begin{array}{l}\text { First Graders } \\
\text { Number of } \\
\text { Metaphors }\end{array}$ & $\begin{array}{l}\text { Percentage } \\
(\%)\end{array}$ & $\begin{array}{l}\text { Fourth Graders } \\
\text { Number of } \\
\text { Metaphors }\end{array}$ & $\begin{array}{l}\text { Percentage } \\
(\%)\end{array}$ \\
\hline Warm and friendly teacher & 69 & 37.7 & 25 & 19.2 \\
Highly-qualified teacher & 19 & 10.3 & 31 & 23.8 \\
Student-centered teacher & 23 & 12.5 & 32 & 24.6 \\
Information-source teacher & 26 & 14.2 & 7 & 5.3 \\
Coherent teacher & 10 & 5.4 & 2 & 1.5 \\
Leading teacher & 14 & 7.6 & 12 & 9.2 \\
Self-improving teacher & 16 & 8.7 & 13 & 10 \\
Lesson-focused teacher & 2 & 1.0 & 3 & 2.3 \\
Authoritarian teacher & 4 & 2.1 & 4 & 3.0 \\
\hline
\end{tabular}


When Table 5 is examined, in the themes of warm and friendly teacher, highly-qualified teacher, student-centered teacher and information-source teacher, relatively distinct differences are seen between the first and fourth graders. The differences show that the students in the first grade want a warm and friendly, highly qualified and knowledgeable teacher who removes distances from their students. On the other hand, the fourth-grade students wish to have a teacher who is very interested in his students, who takes them as the centre of his profession, and have many different roles as well as human values and many different features. Their views about other themes are considered similar as there are slight differences.

\section{Perceptions of Candidate teachers for the Concept of "Student in Their Dreams "}

As a result of the analysis, it was found that the candidate teachers produced 299 metaphors for the concept of student in their dreams, and these metaphors are seen to gather under 9 themes. Sample metaphors from the themes and participants for the concept of teacher are shown in Table 6.

Table 6

Sample Metaphors and Themes That All Participants Produced for "Teacher" Concept in Their Dreams/Wishes

Theme 1. Hardworking and responsible student

C180- My dream student is like a lamb. Because the lamb obeys its owner and also is a sweet and charming animal. Likewise, students are sweet, cute beings who listen to teachers and study their lessons.

Theme 2. Highly skilled student

C276- My dream student is like a rabbit with glasses and trainers. Because he is a cute creature who is successful in his lessons with his glasses and jumps out of social stairs with his trainers.

Theme 3. Distinctive student

C268- My dream student is like a rainbow. Because he should have every color:intelligent, naughty, lazy and hardworking.

Theme 4. Normal student

C293-My dream student is like himself. Because we can not contribute much to students by changing them. We can develop them in areas where they are being themselves.

Theme 5. Sympathetic student

C256- My dream student is like a smurf. Because we neither work very hard nor ignore everything. He should be moderate and be able to enjoy being a student.

Theme 6. Questioning and criticizing student

C216- My dream student is like a 3-year-old kid. Because he asks all the questions he wished to learn without worrying at that age. We are not able to ask as many questions as we can.

Theme 7. Obedient student

C195- The student in my dream is like an adult. Because he must listen to the advices and be respectful.

Theme 8. Talented student

C235- My dream student is like Father Geppetto. Because he must be skilled and talented in handicrafts.

Theme 9. Trainable and shapable student

C259- My dream student is like a pure water. Because pure water is clean, clear and not mixed into anything. It becomes what you want.

On the other hand, regarding the grade level, in order to determine the similarities and differences in the perceptions of candidate teachers for the concept of student in their dreams, the related themes are organized according to the frequency percentage. In Table 7, frequency and percentages are shown as to the similarities and differences in the perceptions of candidate teachers for the concept of student in their dreams/wishes according to the grade level. 
Table 7

Percentage of Similarities and Differences in the Perceptions of Participants for the Concept of Student in Their Dreams by Their Grade Level

\begin{tabular}{lllll}
\hline Themes & $\begin{array}{l}\text { First Graders } \\
\text { Number of } \\
\text { Metaphors }\end{array}$ & $\begin{array}{l}\text { Percentage } \\
(\%)\end{array}$ & $\begin{array}{l}\text { Fourth Graders } \\
\text { Number of } \\
\text { Metaphors }\end{array}$ & $\begin{array}{l}\text { Percentage } \\
(\%)\end{array}$ \\
\hline Questioning and criticizing student & 24 & 13.6 & 9 & 7.0 \\
Highly-skilled student & 26 & 14.7 & 24 & 18.1 \\
Obedient student & 7 & 5.3 & 3 & 2.3 \\
Trainable and shapable student & 37 & 21 & 30 & 23.4 \\
Distinctive student & 3 & 1.7 & 4 & 3.2 \\
Sympathetic student & 8 & 4.5 & 7 & 5.4 \\
Normal student & 3 & 1.7 & 3 & 2.3 \\
Hardworking and responsible student & 61 & 34.6 & 45 & 35.1 \\
Talented student & 3 & 1.7 & 2 & 1.5 \\
\hline
\end{tabular}

As seen in Table 7, in the themes of questioning and criticizing student, highly-skilled student and obedient student, relatively distinct differences are seen between the first and fourth graders. The differences show that the students in the first grade prefer to teach curious, querent, questioning, docile and obedient students more than candidate teachers in the fourth grade. On the other hand, it was revealed that fourth grade students are more likely to want students to undertake many different roles. Their views about other themes are considered similar as there are slight differences. The general perception about the concepts of school, teacher and student in the students' dreams is given in Figure 1.

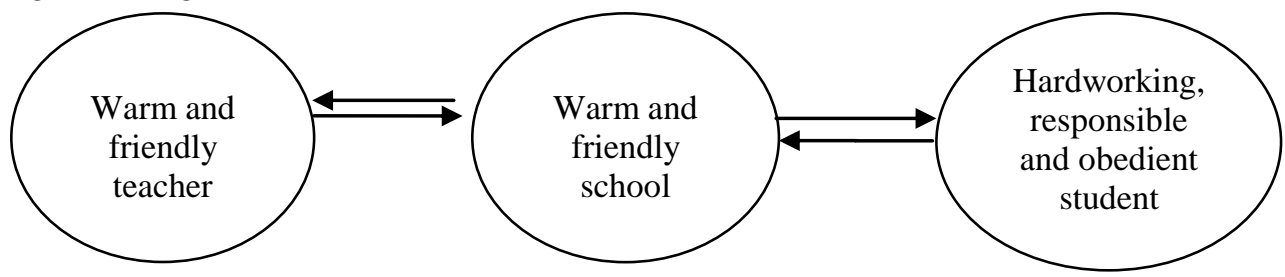

Figure 1

Characteristics of School, Teacher, and Student in Candidate teachers' Dreams

When the common perceptions of students about the concepts of school, teacher and student are taken as a whole, it can be stated that similarly there are warm and sincere relationships, and that, in schools with such an atmosphere, the warm, friendly and sincere teachers teach the hardworking, docile, clever and responsible students.

\section{DISCUSSION AND CONCLUSION}

It was aimed in this research to determine the perceptions of first-grade and fouth-grade candidate teachers studying at the faculty of education of a university on the concept of "school, student and teacher in their dreams" and to evaluate the findings in the context of teacher training. For this purpose, candidate teachers were made produce metaphors for related concepts. Each theme that emerged as the result of the analysis was examined 
according to the grade level of the candidate teachers and it was determined that there are similarities and differences in the perceptions of the candidate teachers about these concepts.

According to the metaphors that the candidate teachers produced for the concept of school in their dreams and that gather under 10 themes, it was determined that the firstand fourth-grade candidate teachers put the most emphasis on warm and friendly school. This finding reveals that the teachers of the future dream of schools with a warm atmosphere where there is a healthy and friendly communication between teachers and students. In other words, this result can be regarded as an important indicator that formal schools with bureaucracies and restricted relationships are not favoured by candidate teachers. It can be said according to this finding that teacher training does not make a difference in the perceptions of the candidate teachers about the atmosphere of and the relationships in the school. Özdemir and Akkaya's (2013) study conducted by high school students and teachers supports the findings of this research in that the participants idealize the school as family and home showing that the students prefer warm and friendly atmosphere in the school. In addition, Simmons, Graham \& Thomas (2015) found in their study with students between the ages of 6-17 that students dreamed of schools with good atmosphere where they would feel happy. Similar findings are also expressed and supported by Osler (2010) and Kostenius (2011). On the other hand, in the studies conducted for the current perception about school (Aydoğdu, 2008; Balc1, 1999; Özdemir, 2012; Saban, 2011), it is seen that the disciplined, authoritarian and bureaucratic structure of the school is emphasized. This contrast explains why candidate teachers idealize schools as warm and friendly atmospheres. It is seen accordingly that the students who feel uncomfortable with the bureaucratic and chaotic atmosphere of the school prefer the schools with effective relationships built through warmth and sincerity.

On the other hand, the metaphors produced by the first and fourth grade candidate teachers seem to differ significantly in the themes of school as information center, entertaining and interesting school, natural and free school, and modern and technological school. It is seen that the first-grade candidate teachers prefer modern, big, technological and entertaining schools more than the fourth-graders. The fourthgrade candidate teachers state that schools which produce and distribute information, are created in more natural environments and offer more freedom to their stakeholders are more likely to be in demand. This difference in perceptions of the first and fourth grade candidate teachers about the school may be due to the undergraduate education and changes in their perceptions or experiences. In other words, the teacher training that candidate teachers receive can lead to a more realistic approach and differentiation in their perceptions. Accordingly, the fourth grade students who are in the last stage of their education and closer to the teaching profession may have taken the school concept more idealistic and, at the same time, more realistically through the activities such as training and school practice. On the other hand, it can be said that first-grade students who are still at the beginning of their vocational education are expecting more sincere and entertaining schools. When the metaphors the general high school students and teachers produced as to the ideal school concept are examined in the study conducted by Özdemir and Akkaya (2013), it is revealed that they want to see the school as a place of 
trust, happiness and excitement. It is similar that general high school students define school as a place of happiness and excitement while first-grade candidate teachers describe it as an entertaining and interesting place. As a result of the study conducted by Simmons, Graham \& Thomas (2015) with the students in the changing age range, it is seen that the students want school to be entertaining. According to this, it is considered that first-grade candidate teachers who are still at the beginning of their vocational education and students in other age groups are similarly using their previous education experiences. Therefore, it is seen in these findings that, with the teacher training they have taken, the perceptions of the candidate teachers differ and the most basic functions of the school such as education come into the forefront. Accordingly, it can be said that undergraduate education in the faculty of education makes a significant difference in the perceptions of students about the school in their dreams.

As a result of the analysis of the metaphors that the candidate teachers produces for the concept of the teacher in their dreams, warm, friendly and sincere teachers become more important than other themes in the first-grade candidate teachers. The teachers who center and focus on their students, and are distinctive, warm and friendly are similarly adopted by the fourth-grade candidate teachers. The findings of Baki and Gökçek's (2007) study seem to be in accord with the emphasis of the fourth-grade candidate teachers on highly-qualified teacher. It is seen as a result of the study that the candidate teachers who adopt schools with warm and friendly atmosphere consider the teachers as part of this warmth and friendliness. It is also noteworthy that candidate teachers attribute the characteristics of their dream teacher to their personal characteristics but do not mention their field or professional knowledge. It is observed, on the other hand, that the differentiation of perception between these two groups is in the characteristics of the teacher in their dreams. Unlike the first-grade students, who emphasize that teachers are warm and sincere people, fourth graders adopt the teacher who is student-centered and interested in them as well as wearing many different roles such as guiding, leading or even being a friend. This perception difference of fourth graders, who integrate teaching more with characteristics and roles, may be a result of undergraduate education. Moreover, the fact that these two groups, in common, do not prefer the teacher to be official and authoritative against their students is an important finding of the study as it is a meaningful answer to the question "What should a good teacher be like?" for many years. Similarly, it is seen in most of the researches trying to determine how the desired teacher should be that the most basic emphasis is put on effective communication features such as warmth and sincerity (Arnon \& Richel, 2007, Gültekin, 2015, Kozikoglu, 2017, Özabacı \& Acat, 2005; Rusu, Shoitu, \& Panaite, 2012; Telli, Brok, \& Çakıroğlu, 2008). It is also revealed in Yıldız and Çınkır's study carried out with graduate and undergraduate students that they prefer the warm and friendly academician characteristics. In Wubbels \& Brekelmans' (2005) review of 20-years researches on teacher-student relations in the classroom, friendly relationships come to the forefront. All these findings are important because they show that a good teacher must be sincere and positive.

When the metaphors produced by the candidate teachers about the concept of student in their dreams are compared on a grade basis, it is seen that the characteristics of the 
dream students of the first and fourth grade candidate teachers are very similar. In both groups, candidate teachers portrayed the student as those who have an adult profile and are aware of responsibilities, intelligent and willing to learn. There are similar studies that idealize students to be responsible, hardworking and mature individuals (Ar1k at al, 1991; Avc1 \& Durmuşçelebi, 2014). In addition, the candidate teachers want these students to take the education given by themselves, and at the same time, to have many different characteristics such as entertaining, cute, obedient and clever. This finding is remarkable in that the candidate teachers generally prefer passive students. It is seen in literature review that the student structure in the perception studies for the students is also in a passive position. In the current perception studies on the student, the research results revealing students as the shaped entities match up with the findings of this study (Aydin \& Pehlivan, 2010, Bozlk, 2002, Çırak, 2014; Saban, 2009, Sezgin at al, 2017). The perceptions about both the adopted and current concepts of student are compatible in terms of passiveness. Similarly, in his study trying to determine what an ideal primary school student is like in the eyes of teachers, Akgül (2015) found that the desired student profile covers the academically passive, hardworking, clever and obedient students. In addition, it is seen that the students who have reached full maturity with moral values are desired by the teachers. These findings are remarkable in that the student is always passively idealized by the teachers and candidate teachers. This result reveals a perception that ignores the student's activities and the problems that he may experience or cause according to his age. Moreover, these findings support the approach of critical theorists such as Freire (2016), Apple (2009), Giroux (2007) and Baker (2013) that students are passivated and filled with stereotypes at school. It is also clear that this passive student perception is contradictory to the student-centered education concept developed in the 21 st century. This situation can be explained as a serious shortcoming of undergraduate education. It can be thought that the teachers and candidate teachers who want their students to only obey the orders, study lesson and be clever beings have such a perception as the result of the standard teacher training they have taken.

In conclusion, it is seen that, for different concepts, candidate teachers have similar perceptions in some themes while having different perceptions in some other themes. These similar and different perceptions may be due to the assumption that the candidate teachers will progress through their point of views throughout the course of their teacher training, and that their educational experiences and understandings in the university do not change their previous educational experience (Leavy, Mcsorley and Bote, 2007). Long-term improvements can be made system-wide through the teacher-educators' positive attitudes towards the profession in teacher education and the practices in the society to increase the status and reputation of the profession.It is possible to reach a general conclusion about what kind of school structure is desired and what basic teacher characteristics are by conducting similar studies at different levels of schools and specifying the characteristics of the dream school, teacher and student. These results can play a role in shaping the future education system and, therefore, in the planning of teacher training for the future. 


\section{REFERENCES}

Akgül, İ. (2015). Sınıf öğretmenlerine göre ideal ilkokul öğrencisi nasıl olmalıdır? Esenler ilçesi örneği. Journal of Research in Education and Training, 4(3), 142-149.

Apple, M. W. (2009). Müfredatın ve eğitimin yeniden yapllandırllmasl/Neoliberalizmin ve yeni-muhafazakarlğ̆ın gündemi. Eleştirel pedagoji söyleşileri (Çev. E. Ç. Babaoğlu). İstanbul: Kakedon Yayınları.

Arık, İ. Arkonaç, A. S. Yılmazer, N., \& Cinan. S. (1991). Bir grup lise öğretmeninin ideal öğrenci ile ilgili algıları. M.K. Atatürk Eğitim Fakültesi Eğitim Bilimleri Dergisi, 17-23.

Arnon, S., \& Reichel, N. (2007) Who is the ideal teacher? Am I? Similarity and difference in perception of students of education regarding the qualities of a good teacher and of their own qualities as teachers. Teachers and Teaching, 13(5), 441-464.

Arslan, M. M., \& Bayrakçı, M. (2006). Metaforik düşünme ve öğrenme yaklaşımının eğitim-öğretim açısından incelenmesi. Milli Eğitim Dergisi, 171, 100-108.

Avcı, Ö. Y., \& Durmuşçelebi, M. (2014). Öğretmen görüşlerine göre ideal öğrenci tipi. Türkiye Sosyal Politika ve Çallş̧ma Hayatı Araştırmaları Dergisi, 4(6), 22-44.

Aydın, İ. (2012). İlköğretim okulu öğrenci, öğretmen ve yöneticilerin okula ilişkin ürettikleri metaforlar ve okul doyumuna ilişkin ipuçları. VII. Ulusal Çocuk Kültürü Kongresi Bildirileri. Ankara. Aydoğdu, E. (2008). İlköğretim okullarında öğrenci ve ögretmenlerin sahip oldukları okul algıları ile ideal okul algllarinın metaforlar yardımıyla analizi. Yayınlanmamış yüksek lisans tezi. Anadolu Üniversitesi, Eskişehir.

Baker, C. (2006). Zorunlu eğitime hayır. (Çev. A. Sönmezay). İstanbul: Ayrıntı Yayınları.

Baki, A., \& Gökçek, T. (2007). Matematik öğretmeni adaylarının benimsedikleri öğretmen modeline ilişkin bazı ipuçları. Hacettepe Üniversitesi Eğitim Fakültesi Dergisi, 32, 22-31.

Balc1, A. (2008). Örgüt mecazları. Ankara: Ekinoks Yayınevi.

Balc1, A. (1999). Metephorical images of school: school perceptions of students, teachers and oarents from four selected schools. Yayınlanmamış doktora tezi, Ortadoğu Teknik Üniversitesi, Sosyal Bilimler Enstitüsü. Ankara.

Başaran, İ. E. (2006). Türk eğitim sistemi ve okul yönetimi. Ankara: Ekinoks Eğitim Danışmanlık ve Basım Yayın.

Bozlk, M. (2002). The college student as learner: insight gained through metaphor analysis. College Student Journal, 36, 142-151.

Casebeer, D. (2015). Mapping preservice teachers' metaphors of teaching and learning. International Journal of Learning, Teaching and Educational Research, 12(3), 13-23. 
Cerit, Y. (2008). Öğrenci, öğretmen ve yöneticilerin okul yöneticisi kavramı ile ilgili metaforlara ilişkin görüşleri. Eğitim ve Bilim, 33(147), 3-12.

Erdem, A. R. (2013). Öğrenci hizmetlerinin yönetimi. İçinde Sarpkaya, R. Türk eğitim sistemi ve okul yönetimi (ss. 247-284). Ankara: An1 Yayınc1lı.

Freire, P. (2016). Ezilenlerin pedagojisi. (Çev. D. Hattatoğlu \& E. Özbek). İstanbul: Ayrıntı Yayınları.

Giroux, H. A. (2007). Eleştirel pedagoji ve neoliberalizm. (Çev. B. Baysal). İstanbul: Kalkedon yayınları.

Gültekin, M. (2015). İlköğretim öğrencilerinin ideal öğretmen algısı. Electronic Turkish Studies, 10(11), 725-756.

Hoy, W. K., \& Miskel, C. G. (2010). Eğitim Yönetimi Teori, Araştırma ve Uygulama (Çev. Edt. Turan, S.). Ankara: Nobel Yayın Dağıtım.

Işıkoğlu, N. (2005). Eğitimde nitel araştırma. Eğitim Araştırmaları, 20, 158-165.

Kostenius, C. (2011). Picture this-our dream school! Swedish schoolchildren sharing their visions of school. Childhood, 18(4), 509-525.

Kozikoğlu, İ. (2017). Prospective teachers' cognitive constructs concerning ideal teacher qualifications: A phenomenological analysis based on repertory grid technique. International Journal of Instruction, 10(3), 63-78.

Leavy, M. A. Mcsorley A. F., \& Bote A. L. (2007). An examination of what metaphor construction reveals about the evolution of preservice teachers' beliefs about teaching and learning. Teaching and Teacher Education, 23, 1217-1233.

Martínez, M. A. Sauleda, N., \& Huber, G. L. (2001). Metaphors as blueprints of thinking about teaching and learning. Teaching and Teacher Education, 17, 956-977.

Milli Eğitim Temel Kanunu (2009). on 20.11.2013 retrieved from http://personel.meb.gov.tr/daireler/mevzuat/mevzuatlar/milli_egitim_temel_kanunu_173 9.pdf

Osler, A. (2010). Students' perspectives on schooling. New York: Open University Press.

Özabacı, N., \& Acat, B. (2005). Öğretmen adaylarının kendi özellikleri ile ideal öğretmen özelliklerine dönük algılarının karşıllaştırılması. Kuram ve Uygulamada Eğitim Yönetimi, 42, 211-236.

Özdemir, M. (2012). Examination of high school students' metaphorical school perceptions in terms of various variables. Education and Science, 37(163), 96-109.

Özdemir, S., \& Akkaya, E. (2013). Genel lise öğrenci ve öğretmenlerinin okul ve ideal okul algılarının metafor yoluyla analizi. Kuram ve Uygulamada Eğitim Yönetimi, 19(2), 295-322. 
Palmquist, R. A. (2001). Cognitive style and users' metaphors for the web: an exploratory study. The Journal of Academic Librarianship, 27 (1), 24-32.

Patton, M. Q. (2014). Nitel araştırma ve değerlendirme yöntemleri (Çev. E. Güzel ve H. Demircioğlu). Nitel araştırmada çeşitlilik. (Çev. Edt: M. Bütün ve S. Demir). Ankara: Anı Yayınc1lık.

Rusu, C. Şoitu, L., \& Panaite, O. (2012). The ideal teacher: Theoretical and investigative approach. Procedia-Social and Behavioral Sciences, 33, 1017-1021.

Saban, A. (2009). Öğretmen adaylarının öğrenci kavramına ilişkin sahip oldukları zihinsel imgeler. Türk Ĕgitim Bilimleri Dergisi, 7(2), 281-326.

Saban, A. (2011). Prospective computer teachers' mental images about the concepts of school and computer teacher. Educational Science Theory and Practise, 11(1), 435-446.

Saban, A. Koçbeker B. N,. \& Saban A. (2006). An investigation of the concept of teacher among prospective teachers through metaphor analysis. Educational Sciences Theory \& Practice, 6(2) 509-522.

Sezgin, F. Koşar, D. Koşar, S., \& Er, E. (2017). A qualitative research on determining teachers' metaphors about students. H. U. Journal of Education, 32(3), 600-61.

Simmons, C. Graham, A., \& Thomas, N. (2015). Imagining an ideal school for wellbeing: Locating student voice. J Educ Change, 16, 129-144.

Şişman, M. (2007). Toplumsal bir aktör müsünüz? İçinde Açıkalın, A. Şişman, M. \& Turan, S. Bir insan olarak okul müdürü. (ss. 38-56). Ankara: Pegem A Yayıncılık.

Şişman, M. (2012). Eğitim bilimine giriş. Ankara: Pegem Akademi.

Telli, S. Den Brok, P., \& Çakiroglu, J. (2008). Teachers' and students' perceptions of the ideal teacher. Egitim ve Bilim, 33(149), 118.

Vadeboncoeur, J. A., \& Torres, M. N. (2003). Constructing and reconstructing teaching roles: a focus on generative metaphors and dichotomies. Discourse: Studies in the Cultural Politics of Education, 24(1), 87-103.

Wubbels, T., \& Brekelmans, M. (2005). Two decades of research on teacher-student relationships in class. International Journal of Educational Research, 43, 6-24.

Yıldırım, A., \& Şimşek, H. (2013). Soysal bilimlerde nitel araştırma yöntemleri. Ankara: Seçkin Yayıncılık.

Yıldız, S., \& Çınkır, Ş. (2015a). Yükseköğretimde öğrenci memnuniyeti: Eğitim Bilimleri Fakültesi örneği. 2. Avrasya Eğitim Araştırmaları Kongresi (EJER), Hacettepe Üniversitesi, Ankara.

Yıldız, S., \& Çınkır, Ş. (2015b). Bir Bologna değerlendirme çalışması: Eğitim Yönetimi ve Teftişi lisansüstü program yeterliklerine ilişskin kazanımların incelenmesi. 1. Bologna Süreci Araştırmaları Kongresi, Hacettepe Üniversitesi, Ankara. 